\title{
Review \\ Efferocytosis Mediated Modulation of Injury after Neonatal Brain Hypoxia-Ischemia
}

\author{
Jana Krystofova Mike ${ }^{1, *}$ and Donna Marie Ferriero ${ }^{1,2}$ \\ 1 Department of Pediatrics, University of California San Francisco, San Francisco, CA 94143, USA; \\ Donna.Ferriero@ucsf.edu \\ 2 Department of Neurology Weill Institute for Neurosciences, University of California San Francisco, \\ San Francisco, CA 94143, USA \\ * Correspondence: Jana.Krystofova@ucsf.edu
}

Citation: Mike, J.K.; Ferriero, D.M. Efferocytosis Mediated Modulation of Injury after Neonatal Brain Hypoxia-Ischemia. Cells 2021, 10, 1025. https://doi.org/10.3390/ cells10051025

Academic Editor: Claire Thornton

Received: 31 March 2021

Accepted: 23 April 2021

Published: 27 April 2021

Publisher's Note: MDPI stays neutral with regard to jurisdictional claims in published maps and institutional affiliations.

Copyright: (c) 2021 by the authors. Licensee MDPI, Basel, Switzerland. This article is an open access article distributed under the terms and conditions of the Creative Commons Attribution (CC BY) license (https:// creativecommons.org/licenses/by/ $4.0 /)$.

\begin{abstract}
Neonatal brain hypoxia-ischemia (HI) is a leading cause of morbidity and long-term disabilities in children. While we have made significant progress in describing HI mechanisms, the limited therapies currently offered for $\mathrm{HI}$ treatment in the clinical setting stress the importance of discovering new targetable pathways. Efferocytosis is an immunoregulatory and homeostatic process of clearance of apoptotic cells (AC) and cellular debris, best described in the brain during neurodevelopment. The therapeutic potential of stimulating defective efferocytosis has been recognized in neurodegenerative diseases. In this review, we will explore the involvement of efferocytosis after a stroke and $\mathrm{HI}$ as a promising target for new HI therapies.
\end{abstract}

Keywords: efferocytosis; stroke; neonatal brain

\section{Introduction}

Efferocytosis represents a physiologic process of phagocytic clearance of AC from the tissue by phagocytic cells promoting the resolution of inflammation [1]. Efferocytosis is carried out by professional phagocytes [2], such as microglia, macrophages, neutrophils or dendritic cells. Selected cells without the primary function of efferocytosis, such as oligodendrocytes are under certain conditions capable of performing efferocytosis, as well and are referred to as "non-professional" phagocytes [3,4]. Efferocytosis is a brain homeostatic process responsible for clearance of AC accumulated in tissue as a result of neurodevelopmental selection or various pathologies. Efferocytosis demonstrates neuroprotective effects through modulation of the local immunoregulatory mechanisms [5]. The timely and rapid containment of AC prevents their death by secondary necrosis that would lead to the release of cellular contents into the environment triggering inflammation [6]. In addition, ingestion of AC inhibits production of proinflammatory cytokines in efferocytes by autocrine and paracrine mechanisms [7], and reprograms efferocytes to release antiinflammatory mediators $[8,9]$, trophic factors $[7,10]$ or bioactive lipids [11] contributing to the resolution of inflammation.

Efferocytosis is a pivotal process of error-free neurodevelopment, where clearing of unnecessary cells and synapses ensures normal redistribution of neural networks. Defective efferocytosis, both excessive or insufficient, contributes to the development of selected neurodevelopmental conditions [12-14]. For example, in Rett syndrome the principal mutation in methyl CpG binding protein 2 (Mecp2) [15] impacts microglial efferocytic functions, among others. The Mecp2-deficient microglia excessively engulf synapses weakened by the loss of Mecp2 expression leading to dismantling neural circuits [16]. The insufficient clearance of cellular debris stimulates the immune system and participates as a substrate for various neuropathologies (Table 1), including autoimmune diseases [17] or neurodegenerative processes, such as multiple sclerosis [18] or Alzheimer's disease [19]. Escaping efferocytosis by overexpression of antiphagocytic signals, such as CD47 is a mechanism 
of brain cancer progression in glioblastoma [20]. Thus, well-functioning efferocytosis is a brain homeostatic and neuroprotective process that helps prevent inflammation $[21,22]$ and contributes to inflammation resolution [23].

Table 1. Defective efferocytosis-based brain pathologies.

\begin{tabular}{|c|c|}
\hline Pathological Condition & Observed Defects in Efferocytosis \\
\hline Glioblastoma [24] & $\begin{array}{c}\text { Overexpression of “don't eat me" CD47 leading to } \\
\text { efferocytosis escape }\end{array}$ \\
\hline Alzheimer's disease $[19,25]$ & $\begin{array}{l}\text { Accumulation of the plaque } \\
\text { Loss of TREM2 reduces phagocytic clearance of the plaque }\end{array}$ \\
\hline Rett syndrome [16] & Excessive engulfment of synapses \\
\hline Down syndrome [26] & $\begin{array}{l}\text { Overactive microglia with altered neuronal dendritic-spine } \\
\text { turnover in hippocampus }\end{array}$ \\
\hline Neurodegeneration [27] & Failure to recognize distressed but viable neurons after stroke \\
\hline Parkinson's disease [28] & $\begin{array}{l}\text { C3-complement system-induced phagocytosis of } \\
\text { dopaminergic neurons } \\
\text { Ineffective } \alpha \text {-syn clearance from degenerating neurons }\end{array}$ \\
\hline Multiple sclerosis [29] & $\begin{array}{c}\text { Internalizing the intact myelin; insufficient clearance of } \\
\text { damaged myelin }\end{array}$ \\
\hline
\end{tabular}

Could efferocytosis be harmful? While most of the studies describe efferocytosis as a neuroprotectant, some studies show possible detrimental effects. In the early phase of injury, a portion of the distressed penumbral neurons with potential for recovery reversibly expose phosphatidylserine, which is recognized by efferocytes as "eat me" signaling and prompts ingestion mediated by milk-fat globule EGF factor-8 (MFG-E8), thereby causing neuronal death [30]. While these neurons microscopically appear intact, it is possible that their apoptotic program is already turned on [31]. Similar observations are described during phagocytosis of lymphocytes that have undergone plasma membrane alterations of apoptosis without yet manifesting the nuclear condensation of apoptosis [32]. It is possible that this phase of efferocytosis is hard to precisely detect by current methods [33]. However, the inhibition of phagocytosis after transient brain ischemia prevents delayed neuronal loss and death of functional neurons [27]. Therefore, when evaluating mechanisms of efferocytosis, it is important to consider the limitations of detection of this pathway and consider the time points studied, especially in the rapidly developing neonatal brain where developmental changes in efferocytosis are not well-studied.

\section{Regulation of Efferocytosis in Brain}

\subsection{Efferocytosis Signaling}

Efferocytosis can be divided into four main phases that employ specific signaling. The first phase is initiated by "find me" signaling originating from AC that mediates recruitment of the efferocyte. The second "eat me" phase is triggered by signaling allowing the efferocyte to recognize the AC and initiate the "engulfment" phase of the AC, followed by "digestion" of the engulfed AC by the efferocyte [34].

Efferocytes have unique characteristics enabling them successfully to eliminate the $\mathrm{AC}$ from the tissue. The engulfment of the first AC triggers changes allowing engulfment of further cells in the process called continual efferocytosis [35,36]. The capacity of an efferocyte to ingest multiple cells subsequently $[37,38]$, as well as the ability to digest a high load of nutrients from multiple ingested cells [39] ensures the necessary fast and efficient clearance of the $\mathrm{AC}$ from the injury site.

Efferocytes respond to multiple stimuli in the injured environment. Yet, efferocytes must recognize dead cells exhibiting "find me" signals that differ depending on the tissue and type of injury [40] (e.g., lysophosphatidylcholine-LPC, sphingosine-1-phosphateS1P, CX3C motif chemokine ligand 1-CX3CL1, nucleotides adenosine triphosphate-ATP 
and uridine triphosphate-UTP) [41-44] and "eat me" signals (phosphatidylserine-PtdSer, calreticulin-Calr, intracellular adhesion molecule 3-ICAM3) [45-48] from distressed cells that release "help me" signals (interleukin-34, fibroblast growth factor 2, lipocalin-2) [49] and healthy cells with "don't eat me" signals (CD31, CD47) [45,50]. Interestingly, some cells secrete "keep out signals", for example, lactoferrin to selectively exclude certain efferocytes, such as eosinophils or neutrophils $[45,51]$ underlying the cellular specificity of the efferocytosis process (Figure 1).

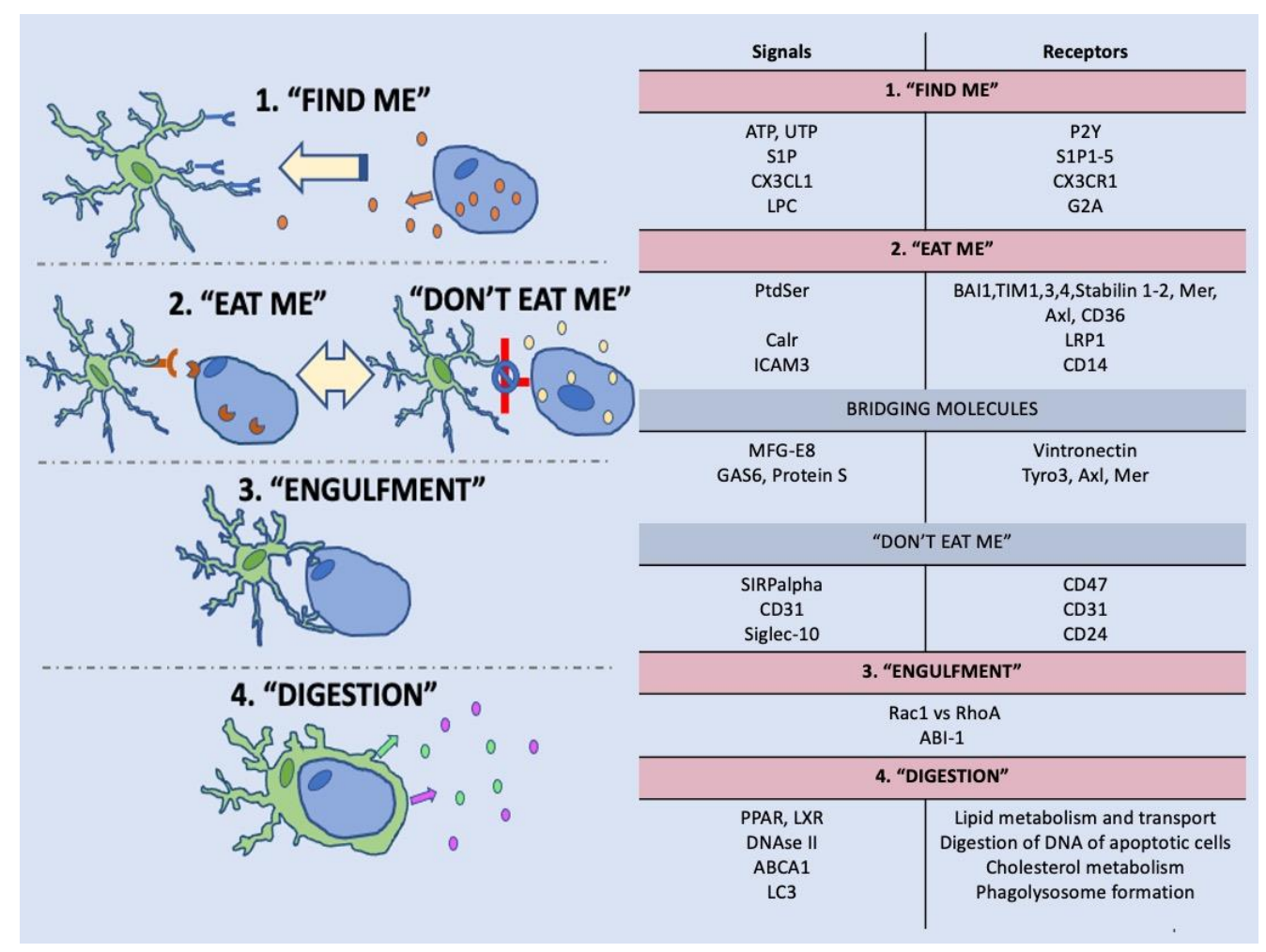

Figure 1. Four steps of efferocytosis: "Find me", eat me", "engulfment", and "digestion" phase represent four main steps of efferocytosis characterized by a high level of complexity of their regulation that involves multiple signaling molecules, receptors, and pathways [30,34,43,45,48,52-62]. The engulfment of AC can promote the anti-inflammatory response of the efferocyte [63]. P2Ypurinergic P2Y receptor, S1P1-5- sphingosine 1-phosphate receptor subtype 1-5, CX3CR1- C-X3-C Motif Chemokine Receptor 1, G2A- G protein coupled receptor Gpr132, TIM- T cell immunoglobulin mucin receptor, Tyro3, Axl, Mer- TAM receptor tyrosine kinases, LRP1- LDL receptor related protein 1, ABI-1- Abl interactor 1, LC3- microtubule associated protein 1A/1B light chain 3, SIRPalphasignal-regulatory protein-alpha, Siglec-10- sialic acid binding Ig-like lectin 10.

One of the best described "eat me" signals is phosphatidylserine, which is normally confined to the inner cytoplasmic leaflet of the plasma membrane by a "flippase". Apoptosis activates a "scramblase" that quickly exposes phosphatidylserine on the cell surface [64] and stimulates a wide range of immunological responses, including the activation of antiinflammatory and immunosuppressive pathways that prevent both local and systemic immune activation [65]. Other groups of signals capable of triggering efferocytosis in parallel with chemotactic signals are electrostatic signals resulting from damage of the cellular membrane [66]. In a model of endothelial efferocytosis, the endothelial AC were strongly negatively charged and attracted positively charged endothelial cells triggering reorganization of their cytoskeleton and sprouting [66]. The most abundant negatively charged structure in eukaryotic membranes is phosphatidylserine [65]. Phosphatidylserine is a glycerophospholipid with the ability to direct proteins with a positive charge $[65,67]$. The function of externalized phosphatidylserine as an "eat me" signal is complex and 
depends on the critical concentration or topology on the cell membrane [65]. A unique role in efferocytosis play selected soluble proteins (growth-arrest specific 6- Gas6, milk fat globule EGF factor 8- MFG-E8, protein S, C1q) that provide the link between the phagocyte and apoptotic cells by binding both to apoptotic signals on the AC, such as phosphatidylserine and the receptors on the phagocytes [45]. The engulfment phase is characterized by the activation of signaling pathways involved in cytoskeletal rearrangement. One of the fundamental regulators of formation and closure of the phagocytic cusp are Rho-family GTP-ases Rac Family Small GTPase 1 (Rac1) and Ras Homolog Family Member A (RhoA) that antagonistically regulate cytoskeletal rearrangement during efferocytosis [68]. Rac1 activates actin reorganization and facilitates the engulfment, whereas RhoA exhibits inhibitory functions [68]. Multiple signals and pathways are involved in Rac1 activation, including the Brain-specific angiogenesis inhibitor 1 (BAI-1) or integrin $\alpha \mathrm{v} \beta 5$ that couple with CrkII-Dock180-ELMO complex [69,70], the CED-1/MEGF10 or stabilin-2 via the CED-6/GULP adapter protein [60] or ABI-1 signaling pathway acting independently of the CED-10 Rac pathway or through CED-10 Rac [71]. The effective formation of the phagosome requires separation of the phagosome from the plasma membrane achieved by dynamin-actin crosstalk [72]. The phagosome undergoes further maturation leading to activation of signaling molecules and genes involved in degradation of its contents, such as regulators of lipid metabolism (ATP Binding Cassette Subfamily A Member 1- ABCA1, liver $\mathrm{X}$ receptor- $\mathrm{LXR}$, peroxisome proliferator-activated receptor- PPAR) or nucleic acids (deoxyribonuclease II- DNAse II), etc. [34]. The efferocytosis signaling is a very complex but tightly regulated process to maintain homeostasis and health of the brain.

\subsection{Cellular Specific Response}

To perform flawless efferocytosis, efferocytes employ multiple receptors. Phosphatidylserine receptor, scavenger receptors, opsonin, complement, and pattern recognition receptors are all involved in the uptake of AC. These receptors are expressed in different densities on microglia, astrocytes, as well as neurons [73] resulting in efferocyte-AC specific responses. Specific AC activates AC-specific efferocytes. For example, in the model of autoimmune encephalitis, the apoptotic lymphocytes are ingested by microglia, oligodendrocytes, and astrocytes [32]. A specific AC activates gene expression signatures unique to each efferocyte, including metabolic and immunoregulatory genes [74] that influence the morphologic, metabolic, and inflammatory state of the efferocyte. This activation may happen by the exposure to AC only or can be prompted by the ingestion of the AC. Exposure of the efferocyte to AC induces SLC2A1-mediated glucose uptake resulting in a robust induction of an aerobic glycolysis program necessary for actin polymerization, continuous efferocytosis, and the establishment of an anti-inflammatory tissue environment via the SLC2A1-released lactate [8]. Efferocytes leverage AC metabolites, as AC engulfment elevates intracellular fatty acids concentration, which fuel mitochondrial respiration leading to anti-inflammatory reprogramming and IL-10 secretion [63].

\subsection{Tissue Specific Response}

An additional level of complexity to the regulation of efferocytosis is highlighted by a phagocyte-tissue specific response as represented by the response of phagocytes to phosphatidylserine. The phosphatidylserine receptor, T-cell immunoglobulin-, and mucin-domain-containing molecule (Tim4) is required for the efficient efferocytosis by resident peritoneal macrophages, Kupffer cells, and $\mathrm{CD} 169^{+}$skin macrophages, whereas thioglycollate-elicited peritoneal macrophages and cultured microglial efferocytosis are independent of Tim4 [62]. In vivo, however, while Tim4-lacking microglia are still able to recognize the AC, they exhibit distinct clearance defects. Specifically, Tim4 is required for phagosome stabilization and brain-specific angiogenesis inhibitor 1 (BAI1) controls the formation of phagosomes around dying neurons and cargo transport [75]. Tim4, together with BAI1 are crucial for efficient microglial performance of efferocytosis in vivo underlying the importance of comparing the in vivo vs. in vitro cell culture studies and 
considering the tissue-specificity of efferocytosis. The spatiotemporal location in the brain defines the regulatory pathways of efferocytosis, as well. In neurogenic regions of the adult mice brain, microglial efferocytic functions depend on TAM receptor tyrosine kinases Mer and Axl and both TAM receptor ligands, growth arrest specific gene 6 (Gas6) and protein S signaling [76]. Gas6 stimulates phagocytosis by bridging the phosphatidylserine residues on the surface of AC to the Axl/Mer [77]. The deficiency in microglial Mer and Axl leads to the marked accumulation of AC specifically in neurogenic regions of the CNS [76]. Similarly to phosphatidyserine, the Gas6 has a dual effect of stimulation of efferocytosis, as well as on limiting inflammation as the Gas6 also suppress lipopolysaccharide-induced expression of the inflammatory molecules IL- $1 \beta$ and iNOS expression through suppression of promoter activity [77]. The understanding of the whole orchestra of interactions necessary for the process of efferocytosis is just beginning, but the regulatory pathways of efferocytosis seem to be tissue, AC, event, and phagocyte-specific. The timing after injury and developmental stage likely play a role, as well. This may be true especially for the neonatal brain, as profound differences have been described in response to injury such as brain HI [78,79].

\subsection{Brain Efferocytosis Signals: IL-4-STAT6-PPAR $\gamma$-Arginase-1 Pathway}

The interleukin-4 (IL-4)-signal transducer and activator of transcription 6 (STAT6)peroxisome proliferator-activated receptor- $\gamma(\operatorname{PPAR} \gamma)$-arginase- 1 (Arg1) signaling axis is one of the key pathways regulating microglial/macrophage efferocytosis in the HI brain. IL-4 is an upstream regulator of PPAR $\gamma$ via STAT6. STAT6 amplifies the PPAR $\gamma$ activity via binding to the enhancer of PPAR $\gamma$ target genes [80].

In the post-ischemic brain, the nuclear receptor PPAR $\gamma$ and STAT6 are the only two upstream regulators predicted to be strongly activated in brain macrophages. The downstream targets of these two regulators include anti-inflammatory factors and growth factors (e.g., IL-10, Arg 1, IGF1, LIF, GDF-15, FGF1), nuclear receptors (e.g., LXR- $\alpha$, NR4A1), and efferocytic receptors and transporters (e.g., CD36, ABCA1) [81]. PPAR $\gamma$ is a liganddependent transcription factor that regulates the expression of specific target genes [82], including genes involved in regulating efferocytosis. PPAR $\gamma$ is induced during annexin 1-mediated microglial efferocytosis of apoptotic neurons [83], and also regulates CD36mediated phagocytosis in the hemorrhagic stroke model [84]. In addition, PPAR $\gamma$ regulates inflammation by interaction with other transcriptional factors and signaling proteins, such as NFKB, by transrepression of MAP kinases or by repressing the transcription of inflammatory mediator genes [82]. In focal cerebral ischemia, PPAR $\gamma$ inhibits COX-2 and decreases expression of iNOS and IL-1 $\beta$ [85]. Similarly to PPAR $\gamma$, STAT6 also regulates efferocytosis of neurons and inflammatory gene signature in microglia/macrophages. STAT6 deficiency results in an enlarged infarct volume and worse neurological outcomes early after an experimental stroke [23].

Arg1 is a downstream target of PPAR $\gamma[83,86]$ and STAT6 [87]. Additional regulatory molecules of efferocytosis, such as annexin-A1 [88] and IL-4 [87], have been shown in independent studies to be associated with increased Arg1 expression. Arg1 synthesis at the injury site is stimulated by the L-arginine released from AC [35] or mechanically by elongation of macrophages [89] and is associated with the macrophage switch towards the antiinflammatory phenotype [89,90]. Arg1 exhibits multiple effects on efferocytosis (Figure 2). During the engulfment phase, Arg1 impacts efferocytosis mechanistically by regulation of the phagolysosome formation. The key cell biological process in AC internalization is actin remodeling around the forming phagosome [91]. Arg1 metabolizes L-arginine released from AC to polyamines and promotes Rac1 activation resulting in actin polymerization for formation of cytoskeleton of the phagosome [35]. In addition, Arg1 is vital for continuous efferocytosis. While Arg1 deletion has no effect on the ingestion of the first AC during efferocytosis, it inhibits the ingestion of the subsequent $\mathrm{AC}$, thus impacting the performance of the continuous efferocytosis [35]. Arg1 regulates the digestion phase of efferocyte, as well. The lack of Arg1 leads to the reduction of Ragulator-Rag complex, an essential regulator of microglial lysosomal activity [92], resulting in impairment of microglial digestion [93]. 
Furthermore, Arg1 contributes to the control of inflammation achieved by suppression of nitric oxide (NO) and superoxide production [94], etc. These findings suggest the pivotal role for Arg1 in microglial efferocytosis, underlined by findings of decreased phagocytosis in rat microglial cells after Arg1 repression by siRNA [93]. Arg1 is primarily abundant in activated microglia and macrophages during early stages of neurodevelopment and after neonatal HI in comparison to the adult brain [95]. Therefore, we can speculate that the process of Arg1 related efferocytosis is highly developmentally-dependent and significantly impacts neuroinflammation and neuroregeneration after $\mathrm{HI}$ injury.

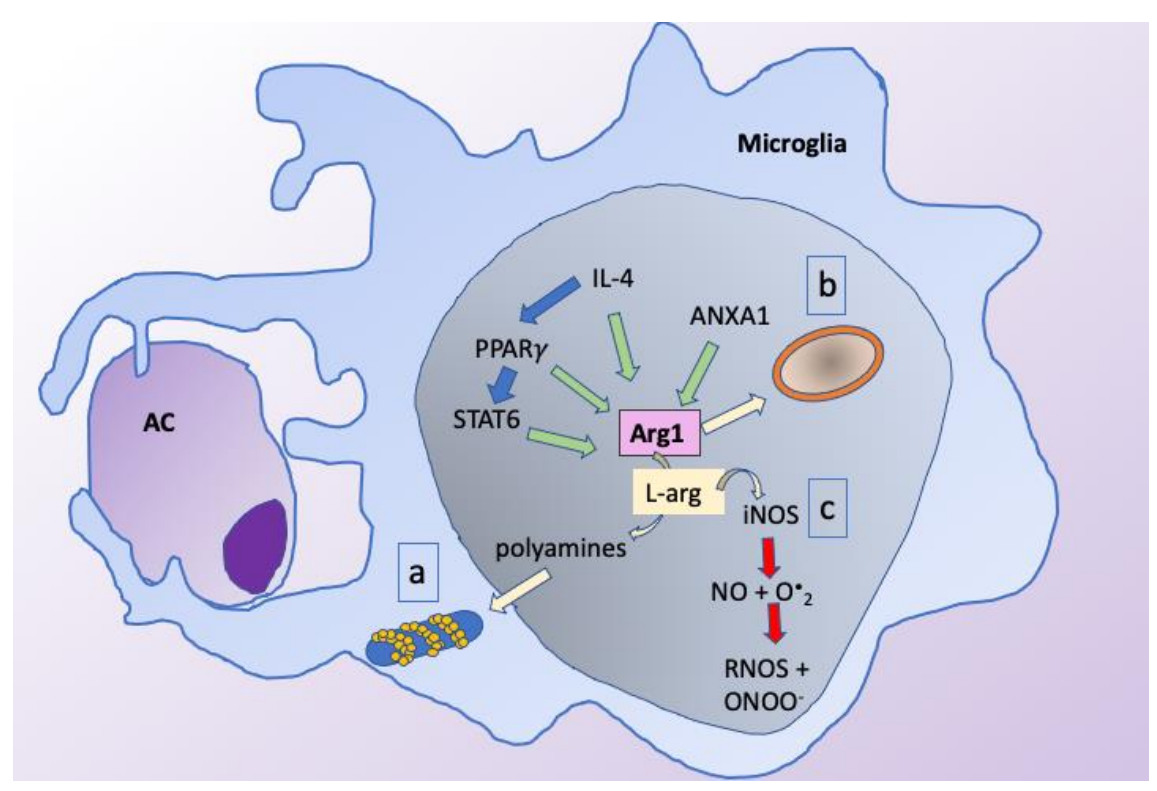

Figure 2. Different roles of Arg1 in efferocytosis: Arg1 is a downstream target of multiple regulators of efferocytosis. Arg1 is involved in engulfment by regulation of phagolysosome formation (a) in lysosomal digestion (b) and exhibits anti-inflammatory effects by reducing NO radical formation (c).

\section{Brain Efferocytes: Microglia and Beyond}

\subsection{Brain Efferocytes}

The major professional phagocytes performing efferocytosis in the brain under normal conditions and in disease are resident microglia [96]. Peripheral blood macrophages are involved in efferocytosis upon the insult [81], but it is unclear whether they participate in the maintenance of brain homeostasis also under normal conditions. The "non-professional" efferocytes include oligodendrocytes [4,32,97], astrocytes [98], endothelial cells [99,100], pericytes [101,102] in the brain or Schwann cells in the peripheral nervous system [103], etc. The "non-professional" efferocytes substantially contribute to brain efferocytosis, as well. Astrocytes eliminate synapses either by direct engulfment or indirectly. The direct engulfment utilizes the MERTK and MGEF10 phagocytic pathways that both recognize the "eat me" signals such as phosphatidylserine residues on the AC [104,105]. The indirect engulfment is carried out by TGF- $\beta$ secreting astrocytes. TGF- $\beta$ induces the C1q expression in retinal ganglion cells leading to opsonization of the unwanted synapses that are subsequently eliminated by complement-mediated microglial phagocytosis [106,107]. In addition to synaptic clearance, astrocytes participate in engulfment of the neuronal $\mathrm{AC}$, as well. In cerebellum, astrocytes engulfed the apoptotic neurons via the MEGF10 pathway [108]. Astrocytes even in a healthy CNS express TAM phagocytic receptors and contribute to the clearance of cellular debris especially under circumstances of impaired microglial function [109]. The ability of oligodendrocytes to participate in phagocytosis in the cell culture has been also described [110]. A unique group of efferocytes is formed by doublecortin (DCX)-positive neuronal progenitor cells found within the neurogenic zones during adult neurogenesis. These cells require intracellular engulfment protein ELMO1 
for their function and ELMO1 deficiency reduces the uptake by DCX ${ }^{+}$cells resulting in accumulation of apoptotic nuclei in the neurogenic niches and impaired neurogenesis, suggesting that proper phagocytic functions of $\mathrm{DCX}^{+}$cells significantly contribute to adult neurogenesis [111]. It is likely that more cells in the brain capable of efferocytosis are yet to be discovered and that a distinct group of efferocytes is activated during the neurodevelopmental pruning [112] and routine "maintenance" of the brain compared to pathological processes. This is due to the fact that brain efferocytes differ in their ability to execute particular steps of efferocytosis, such as sensing cells, speed of engulfment, digestive capacity, and secretion of trophic anti-inflammatory factors, etc.

\subsection{Differences between Professional and Non-Professional Efferocytes}

Professional efferocytes differ in their ability to execute efferocytosis from non-professional phagocytes. For example, in vivo astrocytes and microglia rapidly polarize their processes towards dying cells within 2 to $3 \mathrm{~h}$ after laser induction of apoptosis. However, microglia take precedence in engulfing the dying cells [113]. The observed onset of efferocytosis is model dependent, as in an in vivo model of focal cerebral ischemia, the phagocytosis of neurons does not occur until at least $24 \mathrm{~h}$ after focal cerebral ischemia [27]. The professional efferocytes regulate efferocytic functions of the nonprofessional efferocytes. For example, macrophages by releasing insulin-like growth factor- 1 and microvesicles redirect the phagocytosis and the type of material engulfed by non-professional efferocytes, specifically limiting the uptake of larger AC [114]. Time-lapse recordings of cells in culture show that professional efferocytes ingest AC faster, within minutes than non-professional efferocytes, where ingestion takes a few hours [31]. While non-professional efferocytes recognize the AC quickly, they delay its ingestion [31,115]. This different timing of ingestion has an important impact on the process of efferocytosis. AC have to appear late in the death process before they can stimulate non-professional efferocytes leaving this process to professional efferocytes [31] which are much more efficient. The digestion of professional efferocytes is also faster, lasting only 1-2 min, compared to hours in non-professional efferocytes [31]. The whole process of microglial efferocytosis in zebrafish takes approximately $20 \mathrm{~min}$ with phagosome formation within $8 \mathrm{~min}$ [75]. These observed differences between the non-professional and professional efferocytes suggest higher phagocytic efficiency of professional efferocytes. However, the non-professional efferocytes are vital in the process of efferocytosis. While the phagocytic efficiency of astrocytes remains lower compared to microglia, astrocytes support efferocytosis later in the injury when the microglial density decreases [113]. Other glial cells, such as NG2 glia also respond to dying cells by rapid polarization of their processes towards the cell corpse. However, only microglia migrate to fully engulf the dying cell and proximal dendrites. The NG2 glial response is observed at 6 $\mathrm{h}$ after exposure and polarization remains at $24 \mathrm{~h}$ despite complete removal of the dead cells [113]. NG2 glia fill the space left following the corpse removal [113], where they may play a role in neuroregeneration, as NG2 glial cells participate in the remyelination and are capable of conversion to neurons and astrocytes $[116,117]$.

\subsection{Differences among Professional Efferocytes}

The differences in performance of efferocytosis exist also among brain professional phagocytes, macrophages, and microglia. In vitro, macrophages respond much faster than microglia when encountering apoptotic neurons resulting in earlier onset and plateau of efferocytosis [23]. Furthermore, macrophages manifest higher phagocytic capacity compared to microglia [118]. However, microglia are vital in the long-term recovery and repair process, as 7 days after a stroke in vivo resident microglia again become the predominant phagocyte, while monocytes diminish in ischemic brain [118]. A different response is seen in the model of spinal cord injury, where microglia are involved in the early response to injury by phagocytosing damaged and degenerating tissue. Later, macrophages of peripheral origin predominantly contribute to phagocytosis but are less efficient at processing CNS debris. Microglia in this model also remain viable longer while 
macrophages die and in situ may contribute to secondary damage [119]. The capacity to clear the AC from the injury site also differs among professional phagocyte subsets. The anti-inflammatory macrophages show a 1.5- to 2-fold higher capacity for both binding and uptake of apoptotic cells compared with dendritic cells and the proinflammatory macrophage phenotype [120]. These fundamental differences in efferocytosis observed based on the tissue, cells, and the trigger suggest that brain efferocytosis is a unique process, where professional and non-professional phagocytes are of equal importance in order to maintain homeostasis.

\section{Efferocytosis during Neurodevelopment and after a Stroke}

\subsection{Neurodevelopmental Aspects of Efferocytosis}

Brain efferocytosis is a robust homeostatic process occurring during neurodevelopment that serves to remove unnecessary and excessive neurons [121] and synapses to ensure proper developmental patterning of the structure and function of the brain [122]. The selected cellular and synaptic clearance continues to adulthood as part of the regulation of neurogenesis [123]. Ongoing efferocytosis in the adult brain determines the final number of newly formed neuroblasts that eventually incorporate into circuitry as observed in the hippocampus [123]. Microglia are known for their fundamental role in regulation of the size of the neural precursor cell pool in the developing cerebral cortex [124] and for synaptic pruning in a developing brain [125]. While the focus has been mostly directed on the microglial role in fine-tuning the brain structure during development, the contribution of non-professional phagocytes to developmental efferocytosis is equally important and cannot be overlooked. Astrocytes are an example of efferocytes vital for synaptic pruning and remodeling [104]. The stage of developmental maturity of the brain likely guides the phagocytic capacity of the efferocytes and impacts the response to a stroke. Efferocytosis is vigorous in the neonatal brain and declines with age [126]. Some of the enzymes involved in efferocytosis, such as Arg1 undergo developmental changes with decreasing levels during neurodevelopment [95]. The developmental efferocytic response to a stroke based on different ages still needs to be understood.

\subsection{Efferocytosis after an Ischemic Stroke}

The ischemic environment after a stroke triggers the genetic reprogramming of efferocytes resulting in their morphological changes, proliferation, and polarization [127]. Microglia and macrophages then differentiate into various phenotypes with specific spatiotemporal patterns at the injury site [128]. The ischemia-induced genomic reprogramming enhances the efferocytic capacity of phagocytes resulting in the upregulation of plasma membrane receptors and extracellular bridge molecules necessary for recognition of AC, a cytoskeletal rearrangement enabling the engulfment of $\mathrm{AC}$ and phagosome internalization and activation of transcription regulators that engage in the production of anti-inflammatory and trophic factors [81]. In addition to stimulatory effects of the injured tissue on efferocytosis, the injured tissue may have the opposite effect and cause microglial dysfunction leading to impaired efferocytosis. A common associated finding of brain HI is glutamate toxicity that leads to neuronal hyperactivity. The widespread ATP release during neuronal hyperactivity blinds microglia to the ATP microgradients released by apoptotic cells as "find me" signals with subsequent accumulation of AC [129]. Thus, the phagocyte-AC-tissue represents a dynamic unit of complex interactions with impact on the neuroprotection that is still not understood.

After a stroke, efferocytes undergo specific spatiotemporal changes at the injury site. Within 24-48 h after injury, a group of microglia form a barrier and surround the lesion possibly to prevent expansion. The protective phenotype expressing Ym1 and CD206, etc., populate the ischemic core [128]. Microglia are faster to enter the core of the injury site, within $24 \mathrm{~h}$, while the motility of astrocytes is slower. Astrocytes locate to the penumbra of the injury site during the later phase of the injury, starting at 3 days post the ischemic insult. The penumbral astrocytes express the ABCA1 pathway molecules, MEGF10 
and GULP1 and participate in phagocytosis of synaptic debris [130]. Astrocytes engulf diffuse apoptotic bodies derived from the dendritic arbors of dying neurons, by polarizing their distal processes without exhibiting cell body migration. Microglia predominantly phagocytose dendrites, cell bodies, and nuclei by migrating towards these structures and completely engulfing them [113]. At 7 days, phagocytosis of neurons and debris removal are prevalent [128]. The coordinated responses by microglia and astrocytes in clearance of neuronal corpses are tightly regulated by the receptor tyrosine kinase Mertk [113], but as for the astrocyte-microglial crosstalk (Figure 3) in brain hypoxic-ischemic injury, we are only beginning to understand. Astrocytes can inhibit the efferocytic function of microglia [131] or stimulate microglial anti-inflammatory phenotype by releasing exosomes containing miR873a-5p [132], while microglial downregulation of P2y1 receptor leads to transformation of astrocytes to neuroprotective phenotype [133]. This communication among cells after a stroke is not limited to microglia-astrocytes only. Pericytes indirectly recruit macrophages to the injury site and promote phagocytic activity in macrophages. The macrophages process myelin debris and produce trophic factors, enhancing PDGFR $\beta$ signaling in pericytes leading to the production of extracellular matrix proteins and oligodendrogenesis [102]. Thus, the process of efferocytosis of dying neurons after a stroke is characterized by active communication among multiple cells taking over specific functions.

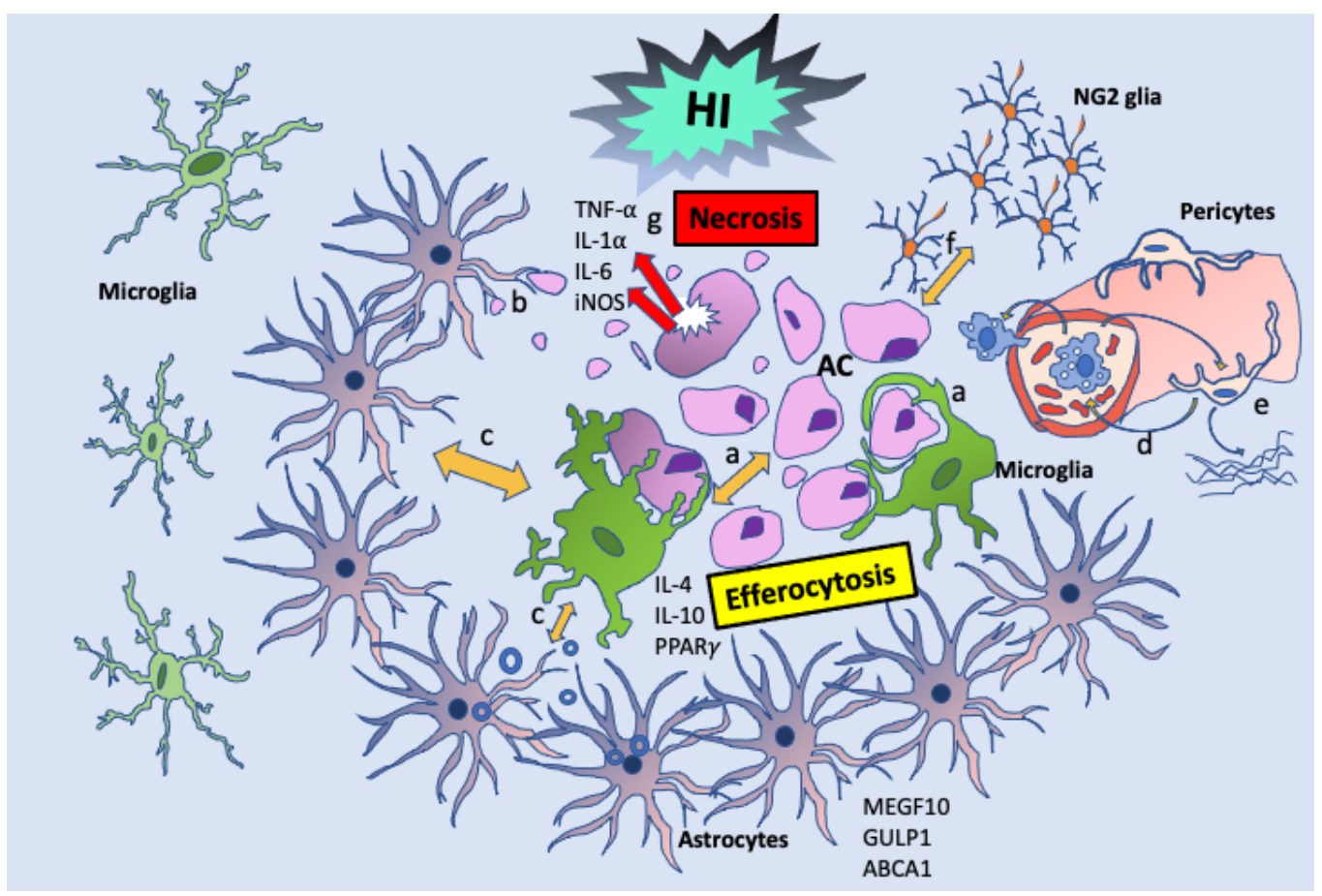

Figure 3. Efferocytosis crosstalk in HI: The AC reprograms efferocytes to express specific gene signatures that regulate the morphologic, metabolic, and inflammatory state of efferocytes. Microglia accumulate at the injury site, where they touch, engulf, and enwrap the AC (a). Astrocytes locate to the penumbra and participate in phagocytosis of synaptic debris (b) [122]. Astrocytes and microglia reciprocally inhibit or stimulate their efferocytic function and anti-inflammatory phenotype (c) [123-125]. Pericytes recruit macrophages and enhance their phagocytic activity (d) and macrophages stimulate pericytes to produce extracellular matrix proteins (e) [98]. NG2 glia fill-in the empty space following AC removal and support neuroregeneration by remyelination and/or conversion to neurons or astrocytes (f) [111,112]. The defective efferocytosis leads to secondary necrosis and inflammation (g), while well-functioning efferocytosis promotes neuroregeneration. 


\section{Efferocytosis as a Therapeutic Modality in Stroke}

\subsection{Timing Approach to Treatment}

Targeting the efferocytosis pathway represents a new promising strategy for stroke therapies. A beneficial approach might be to enhance as well as inhibit efferocytosis. The effects of efferocytosis-targeted therapies for overall post stroke recovery will depend on the timing of their administration after the injury. Early phases of ischemic injury are characterized by infiltration of the reparative microglial/macrophage phenotype that declines over time, and are replaced by the proinflammatory, potentially harmful phenotypes [134]. Therapies aimed at supporting the polarization of efferocyte to the anti-inflammatory phenotype may suppress inflammation and improve outcomes. In early phases, it is important to limit the ingestion of distressed yet viable neurons which could lead to improved neuronal survival. At later time points when efferocytosis is decreased, therapies that stimulate the process of efferocytosis could enhance post stroke recovery [134].

\subsection{Selected Therapies and Translational Potential}

Multiple molecules have been successfully studied and selected molecules are already used as FDA-approved pharmaceuticals for other indications. Administration of PPAR $\gamma$ agonists troglitazone or pioglitazone $24 \mathrm{~h}$ before and at the time of cerebral infarction dramatically reduced infarction volume and improved neurological function following middle cerebral artery occlusion in rats [85]. The beneficial effects are observed also later after the injury at 22 days [85]. Importantly, rosiglitazone has been shown to improve outcomes in patients with Alzheimer's disease [135] and adult stroke [136] supporting the translational potential of efferocytosis-targeted therapies.

Utilizing therapies that mimic products released at the injury site during efferocytosis carries a therapeutic potential, as well. For example, administration of IL-4, a cytokine released after an injury from challenged neurons enhances microglial phagocytosis of AC supporting brain cleanup after an ischemic stroke that translates to better outcomes and decreased lesion volume [137].

A fundamental role to prevent neuroinflammation after a stroke is clearance of myelin debris. Myelin debris is toxic for brain cells as it inhibits remyelination critical for angiogenesis and neurogenesis in post-stroke recovery [138]. Effective clearance of inhibitory myelin debris stimulates neurotrophin synthesis, and formation of blood vessels in a model of spinal cord injury [139]. Restoration of myelin debris phagocytosis can be enhanced by the administration of retinoid X receptor (RXR) agonists [140], PPAR $\gamma$ agonists [141] or the E6020, a synthetic TLR4 agonist [142]. E6020 accelerated myelin debris clearance results in Schwann cell infiltration and remyelination in rat spinal cord [142].

The undesired effects of excessive efferocytosis of distressed yet viable neurons can be prevented by therapies focused on administration of extracellular vesicles containing molecules such as miR-98. In a model of ischemic stroke, miR-98-loaded extracellular vesicles prevented the stressed but viable neurons from microglial phagocytosis [143]. The miR-98 acts via the platelet activating factor receptor (PAFR) that mediates efferocytosis as observed during engulfment of excitatory synapses of hippocampus in a model of experimental auto-immune encephalomyelitis [144] or apoptotic thymocytes in cell culture [145].

Efferocytosis has a vital role in the treatment of the hemorrhagic stroke, as well. While ischemic and hemorrhagic stroke are different pathologies, they share similarities in some of the activated efferocytic signals after injury. For example, the IL-4/STAT6 pathway is one of the canonical pathways of hemorrhage clearance in the brain [146] and STAT6 signaling is activated also after the ischemic stroke [23]. PPAR $\gamma$ agonists, showing neuroprotective effects in an ischemic stroke, help in hemorrhagic stroke by hematoma absorption by 2.3-fold, resulting in decreased neuronal damage, and improved functional recovery [147]. Stimulation of phagocytosis to enhance the clearance of the hematoma is a desirable effect also of the Nrf2 activator, sulforaphane. One possible mechanism is induction of CD36 expression and stimulation of phagocytosis [148]. An 
FDA-approved selective RXR agonist, bexarotene shows effectiveness in both ischemic and hemorrhagic stroke [149]. Treatment of intracerebral hemorrhagic stroke by bexacarotene leads to increased expression of key receptors responsible for erythrophagocytosis by macrophages after intracerebral hemorrhage, including Axl and CD36. The bexarotene treatment enhances erythrophagocytosis and improves neurological outcomes [150].

While efferocytosis after a neonatal brain stroke is a specific process, the overlap in the activation of certain pathways in different brain pathologies and their successful pharmacological targeting could inspire efferocytosis-targeted therapies used in a neonatal stroke.

\section{Conclusions}

Efferocytosis is a known HI pathway but underexplored in the neonatal brain. While it is a pivotal mechanism of clearance of the unnecessary cells and synapses during neurodevelopment, current studies suggest the possible role in neuroprotection. Future studies should focus on exploring the differences in execution of efferocytosis related to neurodevelopment to better understand and define the changes based on the age and timing after an injury. In addition to improving our understanding of the HI pathophysiology, we believe efferocytosis could serve as a source for new therapies for neonatal HI.

Author Contributions: All authors wrote sections of this article and reviewed the completed document. D.M.F. supervised the preparation of the article. All authors have read and agreed to the published version of the manuscript.

Funding: This work was supported by R35-5R35NS097299, UCSF Pediatric Critical Care Division and UCSF Bleecher Bridging Award.

Institutional Review Board Statement: Not applicable.

Informed Consent Statement: Not applicable.

Data Availability Statement: Data sharing not applicable.

Acknowledgments: Special thanks to Praneeti Pathipati, Sandrijn van Schaik, Jeff Fineman, and UCSF Division of Pediatric Critical Care for their help and support.

Conflicts of Interest: The authors declare no conflict of interest and the funders had no role in the design of the study; in the collection, analyses, or interpretation of data; in the writing of the manuscript, or in the decision to publish the results.

\section{References}

1. Kourtzelis, I.; Hajishengallis, G.; Chavakis, T. Phagocytosis of Apoptotic Cells in Resolution of Inflammation. Front. Immunol. 2020, 11, 533. [CrossRef]

2. Rabinovitch, M. Professional and non-professional phagocytes: An introduction. Trends Cell Biol. 1995, 5, 85-87. [CrossRef]

3. Seeberg, J.C.; Loibl, M.; Moser, F.; Schwegler, M.; Büttner-Herold, M.; Daniel, C.; Engel, F.B.; Hartmann, A.; Schlötzer-Schrehardt, U.; Goppelt-Struebe, M.V.; et al. Non-professional phagocytosis: A general feature of normal tissue cells. Sci. Rep. 2019, 9, 11875. [CrossRef] [PubMed]

4. Ludwin, S.K. Phagocytosis in the rat optic nerve following Wallerian degeneration. Acta Neuropathol. 1990, 80, 266-273. [CrossRef] [PubMed]

5. Herzog, C.; Garcia, L.P.; Keatinge, M.; Greenald, D.; Moritz, C.; Peri, F.; Herrgen, L. Rapid clearance of cellular debris by microglia limits secondary neuronal cell death after brain injury in vivo. Development 2019, 146, dev174698. [CrossRef]

6. Silva, M.T.; Vale, A.D.; Santos, N.M.N.D. Secondary necrosis in multicellular animals: An outcome of apoptosis with pathogenic implications. Apoptosis 2008, 13, 463-482. [CrossRef] [PubMed]

7. Fadok, V.A.; Bratton, D.L.; Konowal, A.; Freed, P.W.; Westcott, J.Y.; Henson, P.M. Macrophages that have ingested apoptotic cells in vitro inhibit proinflammatory cytokine production through autocrine/paracrine mechanisms involving TGF- $\beta$, PGE2, and PAF. J. Clin. Investig. 1998, 101, 890-898. [CrossRef]

8. Morioka, J.S.A.S.; Perry, M.H.; Raymond, C.B.; Medina, Y.; Zhu, L.; Zhao, V.; Serbulea, S.; Onengut-Gumuscu, N.; Leitinger, S.; Kucenas, J.C.; et al. Ravichandran, Efferocytosis induces a novel SLC program to promote glucose uptake and lactate release. Nature 2018, 563, 714-718. [CrossRef]

9. Huynh, M.L.N.; Fadok, V.A.; Henson, P.M. Phosphatidylserine-dependent ingestion of apoptotic cells promotes TGF- $\beta 1$ secretion and the resolution of inflammation. J. Clin. Investig. 2002, 109, 41-50. [CrossRef] 
10. Diaz-Aparicio, I.; Paris, I.; Sierra-Torre, V.; Plaza-Zabala, A.; Rodríguez-Iglesias, N.; Márquez-Ropero, M.; Beccari, S.; Huguet, P.; Abiega, O.; Alberdi, E.; et al. Microglia actively remodel adult hippocampal neurogenesis through the phagocytosis secretome. J. Neurosci. 2020, 40, 1453-1482. [CrossRef]

11. Serhan, C.N.; Savill, J. Resolution of inflammation: The beginning programs the end. Nat. Immunol. 2005, 6, 1191-1197. [CrossRef]

12. Roth, K.A.; D'Sa, C. Apoptosis and brain development. Ment. Retard. Dev. Disabil. Res. Rev. 2001, 7, 261-266. [CrossRef]

13. Martens, G.; van Loo, K. Genetic and Environmental Factors in Complex Neurodevelopmental Disorders. Curr. Genom. 2009, 8, 429-444. [CrossRef]

14. Derecki, N.C.; Cronk, J.C.; Lu, Z.; Xu, E.; Abbott, S.B.G.; Guyenet, P.G.; Kipnis, J. Wild-type microglia arrest pathology in a mouse model of Rett syndrome. Nature 2012, 484, 105-109. [CrossRef]

15. Good, K.V.; Vincent, J.B.; Ausió, J. MeCP2: The Genetic Driver of Rett Syndrome Epigenetics. Front. Genet. 2021, 12, 620859. [CrossRef]

16. Schafer, D.P.; Heller, C.T.; Gunner, G.; Heller, M.; Gordon, C.; Hammond, T.; Wolf, Y.; Jung, S.; Stevens, B. Microglia contribute to circuit defects in Mecp2 null mice independent of microglia-specific loss of Mecp2 expression. Elife 2016, 5, 15224. [CrossRef]

17. Poon, I.K.H.; Lucas, C.D.; Rossi, A.G.; Ravichandran, K.S. Apoptotic cell clearance: Basic biology and therapeutic potential. Nat. Rev. Immunol. 2014, 484, 105-109. [CrossRef] [PubMed]

18. Clarke, J.; Yaqubi, M.; Futhey, N.C.; Sedaghat, S.; Baufeld, C.; Blain, M.; Baranzini, S.; Butovsky, O.; Antel, J.; White, J.H.; et al. Vitamin D Regulates MerTK-Dependent Phagocytosis in Human Myeloid Cells. J. Immunol. 2020, 205, 398-406. [CrossRef] [PubMed]

19. Tajbakhsh, A.; Read, M.; Barreto, G.E.; Ávila-Rodriguez, M.; Gheibi-Hayat, S.M.; Sahebkar, A. Apoptotic neurons and amyloidbeta clearance by phagocytosis in Alzheimer's disease: Pathological mechanisms and therapeutic outlooks. Eur. J. Pharmacol. 2021, 895, 173873. [CrossRef] [PubMed]

20. Hutter, G.; Theruvath, J.; Graef, C.M.; Zhang, M.; Schoen, M.K.; Manz, E.M.; Bennett, M.L.; Olson, A.; Azad, T.D.; Sinha, R.; et al. Microglia are effector cells of CD47-SIRP $\alpha$ antiphagocytic axis disruption against glioblastoma. Proc. Natl. Acad. Sci. USA 2019, 116, 997-1006. [CrossRef] [PubMed]

21. Neumann, H.; Kotter, M.R.; Franklin, R.J.M. Debris clearance by microglia: An essential link between degeneration and regeneration. Brain 2009, 132, 288-295. [CrossRef]

22. Iadecola, C.; Anrather, J. The immunology of stroke: From mechanisms to translation. Nat. Med. 2011, 17, 796-808. [CrossRef]

23. Cai, W.; Dai, X.; Chen, J.; Zhao, J.; Xu, M.; Zhang, L.; Yang, B.; Zhang, W.; Rocha, M.; Nakao, T.; et al. STAT6/ Arg1 promotes microglia/macrophage efferocytosis and inflammation resolution in stroke mice. JCI Insight 2019, 14, e131355. [CrossRef] [PubMed]

24. Hu, J.; Xiao, Q.; Dong, M.; Guo, D.; Wu, X.; Wang, B. Glioblastoma Immunotherapy Targeting the Innate Immune Checkpoint CD47-SIRP $\alpha$ Axis. Front. Immunol. 2020, 11, 593219. [CrossRef] [PubMed]

25. Parhizkar, S.; Arzberger, T.; Brendel, M.; Kleinberger, G.; Deussing, M.; Focke, C.; Nuscher, B.; Xiong, M.; Ghasemigharagoz, A.; Katzmarski, N.; et al. Loss of TREM2 function increases amyloid seeding but reduces plaque-associated ApoE. Nat. Neurosci. 2019, 22, 191-204. [CrossRef] [PubMed]

26. Pinto, B.; Morelli, G.; Rastogi, M.; Savardi, A.; Fumagalli, A.; Petretto, A.; Bartolucci, M.; Varea, E.; Catelani, T.; Contestabile, A.; et al. Rescuing Over-activated Microglia Restores Cognitive Performance in Juvenile Animals of the Dp(16) Mouse Model of Down Syndrome. Neuron 2020, 108, 887-904.e12. [CrossRef]

27. Neher, J.J.; Emmrich, J.V.; Fricker, M.; Mander, P.K.; Théry, C.; Brown, G.C. Phagocytosis executes delayed neuronal death after focal brain ischemia. Proc. Natl. Acad. Sci. USA 2013, 110, E4098-E4107. [CrossRef] [PubMed]

28. Tremblay, M.E.; Cookson, M.R.; Civiero, L. Glial phagocytic clearance in Parkinson's disease. Mol. Neurodegener. 2019, 14, 16. [CrossRef]

29. Grajchen, E.; Hendriks, J.J.A.; Bogie, J.F.J. The physiology of foamy phagocytes in multiple sclerosis. Acta Neuropathol. Commun. 2018, 6, 124. [CrossRef]

30. Fricker, M.; Neher, J.J.; Zhao, J.W.; Théry, C.; Tolkovsky, A.M.; Brown, G.C. MFG-E8 mediates primary phagocytosis of viable neurons during neuroinflammation. J. Neurosci. 2012, 32, 2657-2666. [CrossRef]

31. Parnaik, R.; Raff, M.C.; Scholes, J. Differences between the clearance of apoptotic cells by professional and non-professional phagocytes. Curr. Biol. 2000, 10, 857-860. [CrossRef]

32. Nguyen, K.B.; Pender, M.P. Phagocytosis of apoptotic lymphocytes by oligodendrocytes in experimental autoimmune encephalomyelitis. Acta Neuropathol. 1997, 95, 40-46. [CrossRef]

33. Sierra, A.; Abiega, O.; Shahraz, A.; Neumann, H. Janus-faced microglia: Beneficial and detrimental consequences of microglial phagocytosis. Front. Cell. Neurosci. 2013, 7, 6. [CrossRef]

34. Boada-Romero, E.; Martinez, J.; Heckmann, B.L.; Green, D.R. The clearance of dead cells by efferocytosis. Nat. Rev. Mol. Cell Biol. 2020, 21, 398-414. [CrossRef]

35. Yurdagul, A.; Subramanian, M.; Wang, X.; Crown, S.B.; Ilkayeva, O.R.; Darville, L.; Kolluru, G.K.; Rymond, C.C.; Gerlach, B.D.; Zheng, Z.; et al. Macrophage Metabolism of Apoptotic Cell-Derived Arginine Promotes Continual Efferocytosis and Resolution of Injury. Cell Metab. 2020, 31, 518-533.e10. [CrossRef] [PubMed] 
36. Wang, Y.; Subramanian, M.; Yurdagul, A.; Barbosa-Lorenzi, V.C.; Cai, B.; de Juan-Sanz, J.; Ryan, T.A.; Nomura, M.; Maxfield, F.R.; Tabas, I. Mitochondrial Fission Promotes the Continued Clearance of Apoptotic Cells by Macrophages. Cell 2017, 171, 331-345.e22. [CrossRef]

37. Miyanishi, M.; Tada, K.; Koike, M.; Uchiyama, Y.; Kitamura, T.; Nagata, S. Identification of Tim4 as a phosphatidylserine receptor. Nature 2007, 450, 435-439. [CrossRef] [PubMed]

38. Park, D.; Han, C.Z.; Elliott, M.R.; Kinchen, J.M.; Trampont, P.C.; Das, S.; Collins, S.; Lysiak, J.J.; Hoehn, K.L.; Ravichandran, K.S. Continued clearance of apoptotic cells critically depends on the phagocyte Ucp2 protein. Nature 2011, 477, 220-224. [CrossRef]

39. Han, C.Z.; Ravichandran, K.S. Metabolic connections during apoptotic cell engulfment. Cell 2011, 147, 1442-1445. [CrossRef]

40. Hochreiter-Hufford, A.; Ravichandran, K.S. Clearing the dead: Apoptotic cell sensing, recognition, engulfment, and digestion. Cold Spring Harb. Perspect. Biol. 2013, 5, a008748. [CrossRef] [PubMed]

41. Elliott, M.R.; Chekeni, F.B.; Trampont, P.C.; Lazarowski, E.R.; Kadl, A.; Walk, S.F.; Park, D.; Woodson, R.I.; Ostankovich, M.; Sharma, P.; et al. Nucleotides released by apoptotic cells act as a find-me signal to promote phagocytic clearance. Nature 2009, 461, 282-286. [CrossRef]

42. Gude, D.R.; Alvarez, S.E.; Paugh, S.W.; Mitra, P.; Yu, J.; Griffiths, R.; Barbour, S.E.; Milstien, S.; Spiegel, S. Apoptosis induces expression of sphingosine kinase 1 to release sphingosine-1-phosphate as a "come-and-get-me" signal. FASEB J. 2008, $22,107169$. [CrossRef]

43. Truman, L.A.; Ford, C.A.; Pasikowska, M.; Pound, J.D.; Wilkinson, S.J.; Dumitriu, I.E.; Melville, L.; Melrose, L.A.; Ogden, C.A.; Nibbs, R.; et al. CX3CL 1/fractalkine is released from apoptotic lymphocytes to stimulate macrophage chemotaxis. Blood 2008, 112, 162404. [CrossRef]

44. Peter, C.; Waibel, M.; Radu, C.G.; Yang, L.V.; Witte, O.N.; Schulze-Osthoff, K.; Wesselborg, S.; Lauber, K. Migration to apoptotic "find-me" signals is mediated via the phagocyte receptor G2A. J. Biol. Chem. 2008, 283, 5296-5305. [CrossRef]

45. Park, S.Y.; Kim, I.S. Engulfment signals and the phagocytic machinery for apoptotic cell clearance. Exp. Mol. Med. 2017, 49 , e331. [CrossRef] [PubMed]

46. Naeini, M.B.; Bianconi, V.; Pirro, M.; Sahebkar, A. The role of phosphatidylserine recognition receptors in multiple biological functions. Cell. Mol. Biol. Lett. 2020, 25, 23. [CrossRef] [PubMed]

47. Torr, E.E.; Gardner, D.H.; Thomas, L.; Goodall, D.M.; Bielemeier, A.; Willetts, R.; Griffiths, H.R.; Marshall, L.J.; Devitt, A. Apoptotic cell-derived ICAM-3 promotes both macrophage chemoattraction to and tethering of apoptotic cells. Cell Death Differ. 2012, 19, 671-679. [CrossRef] [PubMed]

48. Gardai, S.J.; McPhillips, K.A.; Frasch, S.C.; Janssen, W.J.; Starefeldt, A.; Murphy-Ullrich, J.E.; Bratton, D.L.; Oldenborg, P.A.; Michalak, M.; Henson, P.M. Cell-surface calreticulin initiates clearance of viable or apoptotic cells through trans-activation of LRP on the phagocyte. Cell 2005, 123, 321-334. [CrossRef]

49. Xing, C.; Lo, E.H. Help-me signaling: Non-cell autonomous mechanisms of neuroprotection and neurorecovery. Prog. Neurobiol. 2017, 152, 181-199. [CrossRef] [PubMed]

50. Gardai, S.J.; Bratton, D.L.; Ogden, C.A.; Henson, P.M. Recognition ligands on apoptotic cells: A perspective. J. Leukoc. Biol. 2006, 79, 896-903. [CrossRef]

51. Green, D.R.; Oguin, T.H.; Martinez, J. The clearance of dying cells: Table for two. Cell Death Differ. 2016, 23, 915-926. [CrossRef]

52. Korns, D.; Frasch, S.C.; Fernandez-Boyanapalli, R.; Henson, P.M.; Bratton, D.L. Modulation of macrophage efferocytosis in inflammation. Front. Immunol. 2011, 2, 57. [CrossRef]

53. Lovászi, M.; Haas, C.B.; Antonioli, L.; Pacher, P.; Haskó, G. The role of P2Y receptors in regulating immunity and metabolism. Biochem. Pharmacol. 2021, 114419. [CrossRef]

54. Weigert, A.; Olesch, C.; Brüne, B. Sphingosine-1-Phosphate and Macrophage Biology-How the Sphinx Tames the Big Eater. Front. Immunol. 2019, 10, 1706. [CrossRef]

55. Yang, L.V.; Radu, C.G.; Wang, L.; Riedinger, M.; Witte, O.N. Gi-independent macrophage chemotaxis to lysophosphatidylcholine via the immunoregulatory GPCR G2A. Blood 2005, 105, 1127-1134. [CrossRef]

56. Moffatt, O.D.; Devitt, A.; Bell, E.D.; Simmons, D.L.; Gregory, C.D. Macrophage recognition of ICAM-3 on apoptotic leukocytes. J. Immunol. 1999, 162, 6800-6810. [PubMed]

57. Imbert, P.R.C.; Saric, A.; Pedram, K.; Bertozzi, C.R.; Grinstein, S.; Freeman, S.A. An Acquired and Endogenous Glycocalyx Forms a Bidirectional "Don't Eat" and “Don't Eat Me" Barrier to Phagocytosis. Curr. Biol. 2021, 31, 77-89.e5. [CrossRef] [PubMed]

58. Brugnera, E.; Haney, L.; Grimsley, C.; Lu, M.; Walk, S.F.; Tosello-Trampont, A.C.; Macara, I.G.; Madhani, H.; Fink, G.R.; Ravichandran, K.S. Unconventional Rac-GEF activity is mediated through the Dock180-ELMO complex. Nat. Cell Biol. 2002, 4, 574-582. [CrossRef]

59. Kinchen, J.M.; Ravichandran, K.S. Journey to the grave: Signaling events regulating removal of apoptotic cells. J. Cell Sci. 2007, 120, 2143-2149. [CrossRef] [PubMed]

60. Kim, S.; Park, S.-Y.; Kim, S.-Y.; Bae, D.-J.; Pyo, J.-H.; Hong, M.; Kim, I.-S. Cross Talk between Engulfment Receptors Stabilin-2 and Integrin v 5 Orchestrates Engulfment of Phosphatidylserine-Exposed Erythrocytes. Mol. Cell. Biol. 2012, 32, 2698-2708. [CrossRef]

61. Kawane, K.; Ohtani, M.; Miwa, K.; Kizawa, T.; Kanbara, Y.; Yoshioka, Y.; Yoshikawa, H.; Nagata, S. Chronic polyarthritis caused by mammalian DNA that escapes from degradation in macrophages. Nature 2006, 443, 998-1002. [CrossRef] [PubMed]

62. Yanagihashi, Y.; Segawa, K.; Maeda, R.; Nabeshima, Y.I.; Nagata, S. Mouse macrophages show different requirements for phosphatidylserine receptor Tim4 in efferocytosis. Proc. Natl. Acad. Sci. USA 2017, 114, 8800-8805. [CrossRef] [PubMed] 
63. Zhang, S.; Weinberg, S.; de Berge, M.; Gainullina, A.; Schipma, M.; Kinchen, J.M.; Ben-Sahra, I.; Gius, D.R.; Yvan-Charvet, L.; Chandel, N.S.; et al. Efferocytosis Fuels Requirements of Fatty Acid Oxidation and the Electron Transport Chain to Polarize Macrophages for Tissue Repair. Cell Metab. 2019, 29, 443-456.e5. [CrossRef] [PubMed]

64. Segawa, K.; Nagata, S. An Apoptotic “Eat Me” Signal: Phosphatidylserine Exposure. Trends Cell Biol. 2015, 25, 639-650. [CrossRef] [PubMed]

65. Birge, R.B.; Boeltz, S.; Kumar, S.; Carlson, J.; Wanderley, J.; Calianese, D.; Barcinski, M.; Brekken, R.A.; Huang, X.; Hutchins, J.T.; et al. Phosphatidylserine is a global immunosuppressive signal in efferocytosis, infectious disease, and cancer. Cell Death Differ. 2016, 23, 962-978. [CrossRef]

66. Weihua, Z.; Tsan, R.; Schroit, A.J.; Fidler, I.J. Apoptotic cells initiate endothelial cell sprouting via electrostatic signaling. Cancer Res. 2005, 65, 11529-11535. [CrossRef]

67. Yeung, T.; Gilbert, G.E.; Shi, J.; Silvius, J.; Kapus, A.; Grinstein, S. Membrane phosphatidylserine regulates surface charge and protein localization. Science 2008, 319, 210-213. [CrossRef]

68. Kim, S.Y.; Kim, S.; Bae, D.J.; Park, S.Y.; Lee, G.Y.; Park, G.M.; Kim, I.S. Coordinated balance of Rac1 and RhoA plays key roles in determining phagocytic appetite. PLoS ONE 2017, 12, e0174603. [CrossRef]

69. Albert, M.L.; Kim, J.I.; Birge, R.B. $\alpha(\mathrm{v}) \beta 5$ Integrin recruits the CrkII-Dock180-Rac1 complex for phagocytosis of apoptotic cells. Nat. Cell Biol. 2000, 2, 899-905. [CrossRef]

70. Park, D.; Tosello-Trampont, A.C.; Elliott, M.R.; Lu, M.; Haney, L.B.; Ma, Z.; Klibanov, A.L.; Mandell, J.W.; Ravichandran, K.S. BAI1 is an engulfment receptor for apoptotic cells upstream of the ELMO/Dock180/Rac module. Nature 2007, 450, 430-434. [CrossRef]

71. Hurwitz, M.E.; Vanderzalm, P.J.; Bloom, L.; Goldman, J.; Garriga, G.; Horvitz, H.R. Abl kinase inhibits the engulfment of apopotic cells in Caenorhabditis elegans. PLoS Biol. 2009, 7, 1000099. [CrossRef]

72. Marie-Anaïs, F.; Mazzolini, J.; Herit, F.; Niedergang, F. Dynamin-Actin Cross Talk Contributes to Phagosome Formation and Closure. Traffic 2016, 17, 12386. [CrossRef] [PubMed]

73. Sokolowski, J.D.; Mandell, J.W. Phagocytic clearance in neurodegeneration. Am. J. Pathol. 2011, 178, 1416-1428. [CrossRef]

74. Cummings, R.J.; Barbet, G.; Bongers, G.; Hartmann, B.M.; Gettler, K.; Muniz, L.; Furtado, G.C.; Cho, J.; Lira, S.A.; Blander, J.M. Different tissue phagocytes sample apoptotic cells to direct distinct homeostasis programs. Nature 2016, 539, 565-569. [CrossRef]

75. Mazaheri, F.; Breus, O.; Durdu, S.; Haas, P.; Wittbrodt, J.; Gilmour, D.; Peri, F. Distinct roles for BAI1 and TIM-4 in the engulfment of dying neurons by microglia. Nat. Commun. 2014, 5, 4046. [CrossRef]

76. Fourgeaud, L.; Traves, P.G.; Tufail, Y.; Leal-Bailey, H.; Lew, E.D.; Burrola, P.G.; Callaway, P.; Zagorska, A.; Rothlin, C.V.; Nimmerjahn, A.; et al. TAM receptors regulate multiple features of microglial physiology. Nature 2016, 532, 240-244. [CrossRef] [PubMed]

77. Grommes, C.; Lee, C.Y.D.; Wilkinson, B.L.; Jiang, Q.; Koenigsknecht-Talboo, J.L.; Varnum, B.; Landreth, G.E. Regulation of microglial phagocytosis and inflammatory gene expression by Gas6 acting on the Axl/Mer family of tyrosine kinases. J. NeuroImmune Pharmacol. 2008, 3, 130-140. [CrossRef] [PubMed]

78. Ditelberg, J.S.; Sheldon, R.A.; Epstein, C.J.; Ferriero, D.M. Brain injury after perinatal hypoxia-ischemia is exacerbated in copper/zinc superoxide dismutase transgenic mice. Pediatr. Res. 1996, 39, 204-208. [CrossRef]

79. Lafemina, M.J.; Sheldon, R.A.; Ferriero, D.M. Acute hypoxia-ischemia results in hydrogen peroxide accumulation in neonatal but not adult mouse brain. Pediatr. Res. 2006, 59, 680-683. [CrossRef]

80. Szanto, A.; Balint, B.L.; Nagy, Z.S.; Barta, E.; Dezso, B.; Pap, A.; Szeles, L.; Poliska, S.; Oros, M.; Evans, R.M.; et al. STAT6 transcription factor is a facilitator of the nuclear receptor PPAR $\gamma$-regulated gene expression in macrophages and dendritic cells. Immunity 2010, 33, 699-712. [CrossRef]

81. Zhang, W.; Zhao, J.; Wang, R.; Jiang, M.; Ye, Q.; Smith, A.D.; Chen, J.; Shi, Y. Macrophages reprogram after ischemic stroke and promote efferocytosis and inflammation resolution in the mouse brain. CNS Neurosci. Ther. 2019, 25, 1329-1342. [CrossRef] [PubMed]

82. De Carvalho, M.V.; Gonçalves-De-albuquerque, C.F.; Silva, A.R. PPAR gamma: From definition to molecular targets and therapy of lung diseases. Int. J. Mol. Sci. 2021, 22, 805. [CrossRef]

83. da Rocha, G.H.O.; Loiola, R.A.; Pantaleão, L.d.N.; Reutelingsperger, C.; Solito, E.; Farsky, S.H.P. Control of expression and activity of peroxisome proliferated-activated receptor $\gamma$ by Annexin A1 on microglia during efferocytosis. Cell Biochem. Funct. 2019, 37, 560-568. [CrossRef] [PubMed]

84. Flores, J.J.; Klebe, D.; Rolland, W.B.; Lekic, T.; Krafft, P.R.; Zhang, J.H. PPAR $\gamma$-induced upregulation of CD36 enhances hematoma resolution and attenuates long-term neurological deficits after germinal matrix hemorrhage in neonatal rats. Neurobiol. Dis. 2016, 87, 124-133. [CrossRef] [PubMed]

85. Sundararajan, S.; Gamboa, J.L.; Victor, N.A.; Wanderi, E.W.; Lust, W.D.; Landreth, G.E. Peroxisome proliferator-activated receptor- $\gamma$ ligands reduce inflammation and infarction size in transient focal ischemia. Neuroscience 2005, 130, 685-696. [CrossRef] [PubMed]

86. Ying, W.; Tseng, A.; Chang, R.C.A.; Morin, A.; Brehm, T.; Triff, K.; Nair, V.; Zhuang, G.; Song, H.; Kanameni, S.; et al. MicroRNA223 is a crucial mediator of PPAR $\gamma$-regulated alternative macrophage activation. J. Clin. Investig. 2015, 125, 4149-4159. [CrossRef]

87. Gray, M.J.; Poljakovic, M.; Kepka-Lenhart, D.; Morris, S.M. Induction of arginase I transcription by IL-4 requires a composite DNA response element for STAT6 and C/EBP $\beta$. Gene 2005, 353, 98-106. [CrossRef] [PubMed] 
88. Moraes, L.A.; Kar, S.; Foo, S.L.; Gu, T.; Toh, Y.Q.; Ampomah, P.B.; Sachaphibulkij, K.; Yap, G.; Zharkova, O.; Lukman, H.M.; et al. Annexin-A1 enhances breast cancer growth and migration by promoting alternative macrophage polarization in the tumour microenvironment. Sci. Rep. 2017, 7, 17925. [CrossRef] [PubMed]

89. McWhorter, F.Y.; Wang, T.; Nguyen, P.; Chung, T.; Liu, W.F. Modulation of macrophage phenotype by cell shape. Proc. Natl. Acad. Sci. USA 2013, 110, 17253-17258. [CrossRef] [PubMed]

90. Viola, A.; Munari, F.; Sánchez-Rodríguez, R.; Scolaro, T.; Castegna, A. The metabolic signature of macrophage responses. Front. Immunol. 2019, 10, 1462. [CrossRef]

91. Leverrier, Y.; Ridley, A.J. Requirement for Rho GTPases and PI 3-kinases during apoptotic cell phagocytosis by macrophages. Curr. Biol. 2001, 11, 195-199. [CrossRef]

92. Shen, K.; Sidik, H.; Talbot, W.S. The Rag-Ragulator Complex Regulates Lysosome Function and Phagocytic Flux in Microglia. Cell Rep. 2016, 14, 547-559. [CrossRef]

93. Ma, C.; Hunt, J.B.; Selenica, M.-L.B.; Sanneh, A.; Sandusky-Beltran, L.A.; Watler, M.; Daas, R.; Kovalenko, A.; Liang, H.; Placides, D.; et al. Arginase 1 Insufficiency Precipitates Amyloid- $\beta$ Deposition and Hastens Behavioral Impairment in a Mouse Model of Amyloidosis. Front. Immunol. 2021, 11, 582998. [CrossRef] [PubMed]

94. Fouda, A.Y.; Xu, Z.; Shosha, E.; Lemtalsi, T.; Chen, J.; Toque, H.A.; Tritz, R.; Cui, X.; Stansfield, B.K.; Huo, Y.; et al. Arginase 1 promotes retinal neurovascular protection from ischemia through suppression of macrophage inflammatory responses. Cell Death Dis. 2018, 9, 1001. [CrossRef] [PubMed]

95. Mike, J.K.; Pathipati, P.; Sheldon, R.A.; Ferriero, D.M. Changes in arginase isoforms in a murine model of neonatal brain hypoxia-ischemia. Pediatr. Res. 2020, 89, 830-837. [CrossRef] [PubMed]

96. Fu, R.; Shen, Q.; Xu, P.; Luo, J.J.; Tang, Y. Phagocytosis of microglia in the central nervous system diseases. Mol. Neurobiol. 2014, 49, 1422-1434. [CrossRef]

97. Gaultier, A.; Wu, X.; le Moan, N.; Takimoto, S.; Mukandala, G.; Akassoglou, K.; Campana, W.M.; Gonias, S.L. Low-density lipoprotein receptor-related protein 1 is an essential receptor for myelin phagocytosis. J. Cell Sci. 2009, 122, 1155-1162. [CrossRef]

98. Sloan, S.A.; Darmanis, S.; Huber, N.; Khan, T.A.; Birey, F.; Caneda, C.; Reimer, R.; Quake, S.R.; Barres, B.A.; Paşca, S.P. Human Astrocyte Maturation Captured in 3D Cerebral Cortical Spheroids Derived from Pluripotent Stem Cells. Neuron 2017, 95, 779-790.e6. [CrossRef]

99. Grutzendler, J.; Murikinati, S.; Hiner, B.; Ji, L.; Lam, C.K.; Yoo, T.; Gupta, S.; Hafler, B.P.; Adelman, R.A.; Yuan, P.; et al. Angiophagy prevents early embolus washout but recanalizes microvessels through embolus extravasation. Sci. Transl. Med. 2014, 6, 226 ra31. [CrossRef]

100. Chang, R.; Castillo, J.; Zambon, A.C.; Krasieva, T.B.; Fisher, M.J.; Sumbria, R.K. Brain endothelial erythrophagocytosis and hemoglobin transmigration across brain endothelium: Implications for pathogenesis of cerebral microbleeds. Front. Cell. Neurosci. 2018, 12, 279. [CrossRef]

101. Fisher, M.; French, S.; Ji, P.; Kim, R.C. Cerebral microbleeds in the elderly: A pathological analysis. Stroke 2010, 41, $2782-2785$. [CrossRef] [PubMed]

102. Shibahara, T.; Ago, T.; Tachibana, M.; Nakamura, K.; Yamanaka, K.; Kuroda, J.; Wakisaka, Y.; Kitazono, T. Reciprocal Interaction between Pericytes and Macrophage in Poststroke Tissue Repair and Functional Recovery. Stroke 2020, 51, 3095-3106. [CrossRef] [PubMed]

103. Smith, I.W.; Mikesh, M.; Lee, Y.I.; Thompson, W.J. Terminal Schwann cells participate in the competition underlying neuromuscular synapse elimination. J. Neurosci. 2013, 33, 17724-17736. [CrossRef] [PubMed]

104. Chung, W.S.; Clarke, L.E.; Wang, G.X.; Stafford, B.K.; Sher, A.; Chakraborty, C.; Joung, J.; Foo, L.C.; Thompson, A.; Chen, C.; et al. Astrocytes mediate synapse elimination through MEGF10 and MERTK pathways. Nature 2013, 504, 394-400. [CrossRef]

105. Païdassi, H.; Tacnet-Delorme, P.; Garlatti, V.; Darnault, C.; Ghebrehiwet, B.; Gaboriaud, C.; Arlaud, G.J.; Frachet, P. C1q Binds Phosphatidylserine and Likely Acts as a Multiligand-Bridging Molecule in Apoptotic Cell Recognition. J. Immunol. 2008, 108, 2329-2338. [CrossRef] [PubMed]

106. Stevens, B.; Allen, N.J.; Vazquez, L.E.; Howell, G.R.; Christopherson, K.S.; Nouri, N.; Micheva, K.D.; Mehalow, A.K.; Huberman, A.D.; Stafford, B.; et al. The Classical Complement Cascade Mediates CNS Synapse Elimination. Cell 2007, 131, 1164-1178. [CrossRef]

107. Chung, W.S.; Allen, N.J.; Eroglu, C. Astrocytes control synapse formation, function, and elimination. Cold Spring Harb. Perspect. Biol. 2015, 7, a020370. [CrossRef]

108. Iram, T.; Ramirez-Ortiz, Z.; Byrne, M.H.; Coleman, U.A.; Kingery, N.D.; Means, T.K.; Frenkel, D.; el Khoury, J. Megf10 Is a receptor for C1Q that mediates clearance of apoptotic cells by astrocytes. J. Neurosci. 2016, 36, 5185-5192. [CrossRef]

109. Konishi, H.; Okamoto, T.; Hara, Y.; Komine, O.; Tamada, H.; Maeda, M.; Osako, F.; Kobayashi, M.; Nishiyama, A.; Kataoka, Y.; et al. Astrocytic phagocytosis is a compensatory mechanism for microglial dysfunction. EMBO J. 2020, 39, e104464. [CrossRef]

110. Watabe, K.; Osborne, D.; Kim, S.U. Phagocytic activity of human adult astrocytes and oligodendrocytes in culture. J. Neuropathol. Exp. Neurol. 1989, 48, 499-506. [CrossRef]

111. Lu, Z.; Elliott, M.R.; Chen, Y.; Walsh, J.T.; Klibanov, A.L.; Ravichandran, K.S.; Kipnis, J. Phagocytic activity of neuronal progenitors regulates adult neurogenesis. Nat. Cell Biol. 2011, 13, 1076-1083. [CrossRef] [PubMed]

112. Lee, E.; Chung, W.S. Glial control of synapse number in healthy and diseased brain. Front. Cell. Neurosci. 2019, 13, 42. [CrossRef] [PubMed] 
113. Damisah, E.C.; Hill, R.A.; Rai, A.; Chen, F.; Rothlin, C.V.; Ghosh, S.; Grutzendler, J. Astrocytes and microglia play orchestrated roles and respect phagocytic territories during neuronal corpse removal in vivo. Sci. Adv. 2020, 6, eaba3239. [CrossRef] [PubMed]

114. Han, C.Z.; Juncadella, I.J.; Kinchen, J.M.; Buckley, M.W.; Klibanov, A.L.; Dryden, K.; Onengut-Gumuscu, S.; Erdbrügger, U.; Turner, S.D.; Shim, Y.M.; et al. Macrophages redirect phagocytosis by non-professional phagocytes and influence inflammation. Nature 2016, 539, 570-574. [CrossRef] [PubMed]

115. Lööv, C.; Mitchell, C.H.; Simonsson, M.; Erlandsson, A. Slow degradation in phagocytic astrocytes can be enhanced by lysosomal acidification. Glia 2015, 63, 1997-2009. [CrossRef]

116. Du, X.; Zhang, Z.; Zhou, H.; Zhou, J. Differential Modulators of NG2-Glia Differentiation into Neurons and Glia and Their Crosstalk. Cell. Mol. Neurobiol. 2021, 41, 1-5. [CrossRef]

117. Zhang, Z.; Zhou, H.; Zhou, J. Heterogeneity and Proliferative and Differential Regulators of NG2-glia in Physiological and Pathological States. Curr. Med. Chem. 2019, 27, 6384-6406. [CrossRef]

118. Ritzel, R.M.; Patel, A.R.; Grenier, J.M.; Crapser, J.; Verma, R.; Jellison, E.R.; McCullough, L.D. Functional differences between microglia and monocytes after ischemic stroke. J. Neuroinflamm. 2015, 12, 106. [CrossRef]

119. Greenhalgh, A.D.; David, S. Differences in the phagocytic response of microglia and peripheral macrophages after spinal cord Injury and its effects on cell death. J. Neurosci. 2014, 34, 6316-6322. [CrossRef]

120. Xu, W.; Roos, A.; Schlagwein, N.; Woltman, A.M.; Daha, M.R.; van Kooten, C. IL-10-producing macrophages preferentially clear early apoptotic cells. Blood 2006, 107, 4930-4937. [CrossRef]

121. Nonomura, K.; Yamaguchi, Y.; Hamachi, M.; Koike, M.; Uchiyama, Y.; Nakazato, K.; Mochizuki, A.; Sakaue-Sawano, A.; Miyawaki, A.; Yoshida, H.; et al. Local apoptosis modulates early mammalian brain development through the elimination of morphogen-producing cells. Dev. Cell. 2013, 27, 621-634. [CrossRef]

122. Vilalta, A.; Brown, G.C. Neurophagy, the phagocytosis of live neurons and synapses by glia, contributes to brain development and disease. FEBS J. 2018, 285, 3566-3575. [CrossRef] [PubMed]

123. Sierra, A.; Encinas, J.M.; Deudero, J.J.P.; Chancey, J.H.; Enikolopov, G.; Overstreet-Wadiche, L.S.; Tsirka, S.E.; Maletic-Savatic, M. Microglia shape adult hippocampal neurogenesis through apoptosis-coupled phagocytosis. Cell Stem Cell. 2010, 7, 483-495. [CrossRef] [PubMed]

124. Cunningham, C.L.; Martínez-Cerdeño, V.; Noctor, S.C. Microglia regulate the number of neural precursor cells in the developing cerebral cortex. J. Neurosci. 2013, 33, 4216-4233. [CrossRef] [PubMed]

125. Paolicelli, R.C.; Bolasco, G.; Pagani, F.; Maggi, L.; Scianni, M.; Panzanelli, P.; Giustetto, M.; Ferreira, T.A.; Guiducci, E.; Dumas, L.; et al. Synaptic pruning by microglia is necessary for normal brain development. Science 2011, 333, 1456-1458. [CrossRef] [PubMed]

126. Sendama, W. The effect of ageing on the resolution of inflammation. Ageing Res. Rev. 2020. [CrossRef] [PubMed]

127. Zhang, S. Microglial activation after ischaemic stroke. Stroke Vasc. Neurol. 2019, 57, 101000. [CrossRef] [PubMed]

128. Perego, C.; Fumagalli, S.; de Simoni, M.G. Temporal pattern of expression and colocalization of microglia/macrophage phenotype markers following brain ischemic injury in mice. J. Neuroinflamm. 2011, 8, 174. [CrossRef]

129. Abiega, O.; Beccari, S.; Diaz-Aparicio, I.; Nadjar, A.; Layé, S.; Leyrolle, Q.; Gómez-Nicola, D.; Domercq, M.; Pérez-Samartín, A.; Sánchez-Zafra, V.; et al. Neuronal Hyperactivity Disturbs ATP Microgradients, Impairs Microglial Motility, and Reduces Phagocytic Receptor Expression Triggering Apoptosis/Microglial Phagocytosis Uncoupling. PLoS Biol. 2016, 14, e1002554. [CrossRef]

130. Morizawa, Y.M.; Hirayama, Y.; Ohno, N.; Shibata, S.; Shigetomi, E.; Sui, Y.; Nabekura, J.; Sato, K.; Okajima, F.; Takebayashi, H.; et al. Reactive astrocytes function as phagocytes after brain ischemia via ABCA1-mediated pathway. Nat. Commun. $2017,8,28$. [CrossRef]

131. Dewitt, D.A.; Perry, G.; Cohen, M.; Doller, C.; Silver, J. Astrocytes regulate microglial phagocytosis of senile plaque cores of Alzheimer's disease. Exp. Neurol. 1998, 149, 329-340. [CrossRef]

132. Long, X.; Yao, X.; Jiang, Q.; Yang, Y.; He, X.; Tian, W.; Zhao, K.; Zhang, H. Astrocyte-derived exosomes enriched with miR-873a-5p inhibit neuroinflammation via microglia phenotype modulation after traumatic brain injury. J. Neuroinflamm. 2020, 17, 89. [CrossRef] [PubMed]

133. Shinozaki, Y.; Shibata, K.; Yoshida, K.; Shigetomi, E.; Gachet, C.; Ikenaka, K.; Tanaka, K.F.; Koizumi, S. Transformation of Astrocytes to a Neuroprotective Phenotype by Microglia via P2Y1 Receptor Downregulation. Cell Rep. 2017, 19, 1151-1164. [CrossRef]

134. Ting, S.M.; Zhao, X.; Sun, G.; Obertas, L.; Ricote, M.; Aronowski, J. Brain cleanup as a potential target for poststroke recovery the role of RXR (retinoic X receptor) in phagocytes. Stroke 2020, 51, 958-966. [CrossRef] [PubMed]

135. Wójtowicz, S.; Strosznajder, A.K.; Jeżyna, M.; Strosznajder, J.B. The Novel Role of PPAR Alpha in the Brain: Promising Target in Therapy of Alzheimer's Disease and Other Neurodegenerative Disorders. Neurochem. Res. 2020, 45, 972-988. [CrossRef]

136. Lee, M.; Saver, J.L.; Liao, H.W.; Lin, C.H.; Ovbiagele, B. Pioglitazone for Secondary Stroke Prevention: A Systematic Review and Meta-Analysis. Stroke 2017, 48, 388-393. [CrossRef] [PubMed]

137. Zhao, X.; Wang, H.; Sun, G.; Zhang, J.; Edwards, N.J.; Aronowski, J. Neuronal interleukin-4 as a modulator of microglial pathways and ischemic brain damage. J. Neurosci. 2015, 35, 11281-11291. [CrossRef] [PubMed]

138. Marin, M.A.; Carmichael, S.T. Mechanisms of demyelination and remyelination in the young and aged brain following white matter stroke. Neurobiol. Dis. 2019, 126, 5-12. [CrossRef] [PubMed] 
139. Barrette, B.; Hébert, M.A.; Filali, M.; Lafortune, K.; Vallières, N.; Gowing, G.; Julien, J.P.; Lacroix, S. Requirement of myeloid cells for axon regeneration. J. Neurosci. 2008, 28, 9363-9376. [CrossRef]

140. Natrajan, M.S.; de la Fuente, A.G.; Crawford, A.H.; Linehan, E.; Nuñez, V.; Johnson, K.R.; Wu, T.; Fitzgerald, D.C.; Ricote, M.; Bielekova, B.; et al. Retinoid X receptor activation reverses age-related deficiencies in myelin debris phagocytosis and remyelination. Brain 2015, 138, 3581-3597. [CrossRef]

141. Natrajan, M.S.; Komori, M.; Kosa, P.; Johnson, K.R.; Wu, T.; Franklin, R.J.M.; Bielekova, B. Pioglitazone regulates myelin phagocytosis and multiple sclerosis monocytes. Ann. Clin. Transl. Neurol. 2015, 2, 1071-1084. [CrossRef] [PubMed]

142. Church, J.S.; Milich, L.M.; Lerch, J.K.; Popovich, P.G.; McTigue, D.M. E6020, a synthetic TLR4 agonist, accelerates myelin debris clearance, Schwann cell infiltration, and remyelination in the rat spinal cord. Glia 2017, 65, 883-899. [CrossRef] [PubMed]

143. Yang, J.; Cao, L.L.; Wang, X.P.; Guo, W.; Guo, R.B.; Sun, Y.Q.; Xue, T.F.; Cai, Z.Y.; Ji, J.; Cheng, H.; et al. Neuronal extracellular vesicle derived miR-98 prevents salvageable neurons from microglial phagocytosis in acute ischemic stroke. Cell Death Dis. 2021, 12, 23. [CrossRef] [PubMed]

144. Bellizzi, M.J.; Geathers, J.S.; Allan, K.C.; Gelbard, H.A. Platelet-activating factor receptors mediate excitatory postsynaptic hippocampal injury in experimental autoimmune encephalomyelitis. J. Neurosci. 2016, 36, 1336-1346. [CrossRef]

145. Ferracini, M.; Rios, F.J.O.; Pecenin, M.; Jancar, S. Clearance of apoptotic cells by macrophages induces regulatory phenotype and involves stimulation of CD36 and platelet-activating factor receptor. Mediators Inflamm. 2013, 2013, 950273. [CrossRef] [PubMed]

146. Xu, J.; Chen, Z.; Yu, F.; Liu, H.; Ma, C.; Xie, D.; Hu, X.; Leak, R.K.; Chou, S.H.Y.; Stetler, R.A.; et al. IL-4/STAT6 signaling facilitates innate hematoma resolution and neurological recovery after hemorrhagic stroke in mice. Proc. Natl. Acad. Sci. USA 2020, 117, 32679-32690. [CrossRef]

147. Zhao, X.; Sun, G.; Zhang, J.; Strong, R.; Song, W.; Gonzales, N.; Grotta, J.C.; Aronowski, J. Hematoma resolution as a target for intracerebral hemorrhage treatment: Role for peroxisome proliferator-activated receptor $\gamma$ in microglia/macrophages. Ann. Neurol. 2007, 61, 352-362. [CrossRef]

148. Zhao, X.; Sun, G.; Ting, S.M.; Song, S.; Zhang, J.; Edwards, N.J.; Aronowski, J. Cleaning up after ICH: The role of Nrf2 in modulating microglia function and hematoma clearance. J. Neurochem. 2015, 133, 144-152. [CrossRef]

149. Certo, M.; Endo, Y.; Ohta, K.; Sakurada, S.; Bagetta, G.; Amantea, D. Activation of RXR/PPAR $\gamma$ underlies neuroprotection by bexarotene in ischemic stroke. Pharmacol. Res. 2015, 102, 298-307. [CrossRef]

150. Chang, C.F.; Massey, J.; Osherov, A.; da Costa, L.H.A.; Sansing, L.H. Bexarotene Enhances Macrophage Erythrophagocytosis and Hematoma Clearance in Experimental Intracerebral Hemorrhage. Stroke 2020, 51, 612-618. [CrossRef] 